ISSN: 2599-3496 print

ISSN: 2614-2376 online

\title{
Preliminary Product Acceptance and Initial Price of Virgin Red Palm Oil on African Expatriate Communnity in Jakarta
}

\author{
Mokhamad Syaefudin Andrianto \\ IPB University, Bogor 16680, Indonesia.
}

\begin{abstract}
The development of the palm oil downstream industries is still limited eventhough various products can be made. The market acceptance becomes one of the important considerations. The research objective was to analyze the product acceptance and initial price a new product of virgin red palm oil (VRPO), a kind of red palm oil (RPO), one of the potential downstream palm oil products. A survey was conducted in Jakarta with African expatriate community as respondents. A sample of product VRPO was given to each respondents and after tasted, they filled the questionnaire. The acceptance product perception was measured by likert scale and initial price with the willingness to pay methods was investigated by open ended questions. The results analysed by average aprroached and optimum price used linear and logarithmic regression. This study found that product perception was very good especially in familliarity and reccomendation to buy. The new product was similar to the product available in their origin countries and when the product available, almost $90 \%$ respondents would like to buy the product. Other results showed that packaging was preferred in $1000 \mathrm{~mL}$. The maximum willingnes to pay for $1000 \mathrm{~mL}$ was IDR 150000 and the minimum was IDR 20000 . The average price was IDR 70370 and the optimum price with linear regression approached was IDR 70809 and with the logarithmic regression approached was IDR 62628 . This study provides empirical evidence that the product is prospective eventhough it is still in the limited scope. The range willingness to pay also supports the decision maker to give the initial price.
\end{abstract}

Keywords: innovation, new product development, optimal price, pricing strategy, willingness to pay

\section{INTRODUCTION}

The launching decision is a critical point in a new product development because in this stage, company must decide marketing mix. According to Armstrong et al. (2017) marketing mix is a tactical tools contain mix of product, price, place (channel distribution) and promotion element (4 P's). Product and price should be define firstly before channel distribution and promotion to reach consumers. Product performance for small medium entreprises (SME's) can be measured by customer

\footnotetext{
${ }^{*}$ Corresponding author:

Department of Management, Faculty of Economics and Management, IPB University.

Jalan Agathis, Kampus IPB Dramaga, Bogor 16680, Indonesia.

Email: syaefudin1@apps.ipb.ac.id
} 
acceptance (Healy et al. 2014) and pricing strategy can be selected from three alternatives; customer value based, cost based and competition based strategy (Armstrong et al. 2017).

Palm oil as a national strategic commodity has various benefits that is still being developed for downstream industries. One potential derivative products is red palm oil (RPO), this is a pretreatment product of crude palm oil (CPO) that meets standard edible oil specification. The product has advantages in nutrition contains especially carotene and vitamin E (Nagendran et al. 2000). The product can be used to addresss vitamin A deficiency (Kritchevsky 2000). It is also can be mixed as biscuit fortified in African (Van Stuijvenberg et al. 2000; Zeba et al. 2006), as maternal diet in breast milk (Canfield et al. 2001) and as sugar fortification (Dwiyanti et al. 2014). So It is potential to support national programs to reduce lack of vitamin A (Avitaminosis) that cause problem in eye sight.

Some Indonesian researcher has been developing products based on RPO (Sugiyono et al. 2012; Widarta et al. 2012). Unfortunately, new products based on RPO is still limited in the awareness. Buying decision were affected by price, color, content of nutrients and packaging (Bardhani et al. 2009; Andrianto et al. 2012). When RPO developed as cooking oil, the fried products become reddish and could not acceptable in Indonesian consumer's perception. The product would be better if it develop as a supplement in the form of capsules or tablets (Andrianto et al. 2012). RPO as cooking oil is still difficult to marketed and need more effort to educate Indonesian consumer.

On the other hand, African expatriates are very familiar with virgin red palm oil (VRPO). VRPO is a kind of RPO with traditional methods in processing. It is called virgin because it is processed directly from oil palm fruits without any refining steps. Traditionally, VRPO has been well known in Africa as dietary supplement for thousands of years and Africans emigrants also brought oil palm seeds along with their culture of consumption across North and South America to memorize their hometown. Based on their behavior reasons there is a potential market of VRPO in African expatriate who stay in Indonesia. However it is still rare provided in Indonesian market because of limited consumers. This study focus on exploring a new product acceptance and initial price of VRPO as part of marketing mix elements.

\section{MATERIALS AND METHODS}

The product of VRPO as a sample was provided by a special company in Jonggol because its availability was limited and rare in Indonesian market. In this research, the product was compared to similar traditional product in Africa based on their memory to measure product acceptance and customer based pricing. willingness to pay (WTP) as a customer based pricing approach was used to develop initial pricing.

There are some methods to measure WTP such as conjoint analysis, contingent valuation methods, becker, deGroot and marschack's (BDM), experimental auction and open-ended question format (Wertenbroch \& Skiera 2002; Miller et al. 2011; Leszczyńska 2015). In this study WTP analyses were conducted using contingent valuation methods with open-ended questions.

\section{Data Collection}

Data were gathered from the African expatriate in Jakarta on August 2016 it is estimated that there are ten thousand African people in Indonesia. Because of limited access and samples, 
in this preleminary research, 40 African expatriate respondents were given a sample of $250 \mathrm{~mL}$ VRPO. Sampling methods used convenience sampling and data obtained via an African community leader as an enumerator. Respondents tasted the sample, filled questionnaire and gave back to the enumerator. After collecting and filtering data, only 35 data can be processed.

\section{Data Analysis}

There were two parts of questionnaire about products descriptive and WTP. Products descriptive used Likert scale 1-5 to measure preference. WTP used open-ended questions with assumption all respondents already tasted the products. Products description measured by general interpretation that shown in Table1.

WTP measured by three approached Average WTP, simple regression and logarithmic. Optimum Average Willingness to pay can be calculated by an equation:

$\mathrm{EWTP}=\frac{\sum_{i=1}^{n} W i}{n}$

EWTP, average willingness to pay;

Wi, WTP value to-i;

$\mathrm{N}$, number of respondent;

i, respondent to-i.

\section{Optimum Willingness to Pay}

Optimum price can be obtained from Total Revenue (TR) derivation. Optimum price occur when Marginal Revenue (MR) $=0$.

$$
\mathrm{MR}=\frac{\Delta y}{\Delta x} T R=0
$$

Table 1 Product descriptive interpretation

\begin{tabular}{lcl}
\hline From & To & General interpret \\
\hline 1 & 1.795 & Very bad \\
1.800 & 2.595 & Bad \\
2.600 & 3.395 & Neutral \\
3.400 & 4.195 & Good \\
4.200 & 4.995 & very good \\
\hline
\end{tabular}

$$
\frac{\Delta y}{\Delta x} P(x) Q(y w t p)=0
$$

To made curve demand, two models are proposed to estimate optimized price by linear regression and logarithmic regression. WTP estimation processed with regression formula and optimal pricing derived from regression equation.

\section{Simple Regression Equation}

$\mathrm{y}=\propto+\boldsymbol{\beta} x+\varepsilon$

$y$, quantity of willingness to pay (percentage);

$\propto$, constant;

$\beta$, coefficient of regression;

$\mathrm{xi}$, price;

$\varepsilon$, error.

\section{Logarithmic Equation}

$\mathrm{y}=\alpha+\beta \ln (x)+\varepsilon$

$\mathrm{y}$, quantity of willingness to pay (percentage);

$\propto$, constant;

$\beta$, coefficient of regression;

$\mathrm{xi}$, price;

$\varepsilon$, error.

Coefficient of determination in simple and logarithmic regression is measured by $R^{2}$. Model with higher $R^{2}$ is better.

\section{RESULTS AND DISCUSSION}

\section{Descriptive Product Profile}

There were three packaging sizes of VRPO in $1000 \mathrm{~mL}, 250 \mathrm{~mL}$ and $100 \mathrm{~mL}$ that introduced itabn this research to food grade. The VRPO also was developed in other packaging sizes such as smaller quantity for skin and facial care.

\section{Product Acceptance}

This study showed that the product had good acceptance in African community. They were very familiar and often used similar oil products. its color, consistency (thickness) and tastes were very good. 
Respondents would like to buy and will recommend product to his/her friends if available in the market especially for expatriate (Table 2).

\section{Willingness To Pay (WTP)}

After trial, majority respondents (89\%) expected want to buy VRPO in vary volume packaging. Respondent preference in packaging composition $250 \mathrm{~mL}, 500$ $\mathrm{mL}$ and $1000 \mathrm{~mL}$ were $10 \%, 3 \%$ and $87 \%$ respectively. Based on data from 27 respondents $(87 \%)$, they will buy package in $1000 \mathrm{~mL}$ with minimum price was IDR 20000 and maximum price was IDR 150 000 (Table 3).

\section{Average and Optimum Willingness to Pay}

Based on equation number (1) and Table 3 so average Willingness to Pay is

$$
\mathrm{EWTP}=\frac{\sum_{i=1}^{n} W i}{n}=\operatorname{IDR} 70370
$$

To estimate optimize the price, two models were proposed to develop demand curve that are linear and logarithmic regression. Simple regression has resulted in coefficient determinant $\mathrm{R}^{2}=0.75$ (Figure 1). Whether Logarithmic regression has result coefficient determinant $R^{2}=0.78$ (Figure 2). So, based on coefficient determinants, logarithmic regression model is better than linear regression model.

Table 2 Virgin red palm oil descriptive performance $(n=35)$

\begin{tabular}{lcc}
\hline Questions & Average result & Interpretation \\
\hline What is your first reaction to the product? & 4.54 & Very good \\
How familiar are you with this product type? & 4.80 & Very familiar \\
Would you like to continue to use this product? & 4.66 & Definitely need \\
Do you currently use other similar products? If yes, how often? & 3.43 & often \\
How well does this our product meet your needs? & 4.34 & Very well \\
What do you think about the colour of this product? Reddish enough & 4.29 & Very good \\
What do you think about the consistency (thickness) of this product? & 4.31 & Very good \\
What do you think about the taste of this product? & 4.40 & Very good \\
Did the food prepared taste like what you are used for Red Palm oil? & 4.57 & $>=80 \%$ \\
Overall, how satisfied or dissatisfied are you with the product? & 4.69 & Very satisfied \\
Are you going to recommend this product to a friend or colleague? & 4.77 & Very recommended \\
If the product were available today, how likely you to buy this & 4.74 & Very likely \\
\hline
\end{tabular}

Table 3 Price and willingness to pay $1000 \mathrm{~mL}$

\begin{tabular}{ccccc}
\hline $\begin{array}{c}\text { Price } \\
(\text { IDR Thousands) }\end{array}(\mathrm{p})$ & \begin{tabular}{c} 
Wumber of \\
\cline { 2 - 5 }
\end{tabular} & $\begin{array}{c}\text { Cummulative } \\
\text { respondents }\end{array}$ & $\begin{array}{c}\text { Cumulative WTP (\%) } \\
\text { Total (IDR thousand) } \\
\left(\mathrm{p}^{*} \mathrm{q}\right)\end{array}$ \\
\hline 150 & 2 & 2 & 7.41 & 300 \\
120 & 2 & 4 & 14.81 & 240 \\
75 & 4 & 8 & 29.63 & 300 \\
70 & 1 & 9 & 33.33 & 70 \\
65 & 2 & 11 & 40.74 & 130 \\
60 & 9 & 20 & 74.07 & 540 \\
50 & 6 & 26 & 96.30 & 300 \\
20 & 1 & 27 & 100.00 & 20 \\
\hline
\end{tabular}




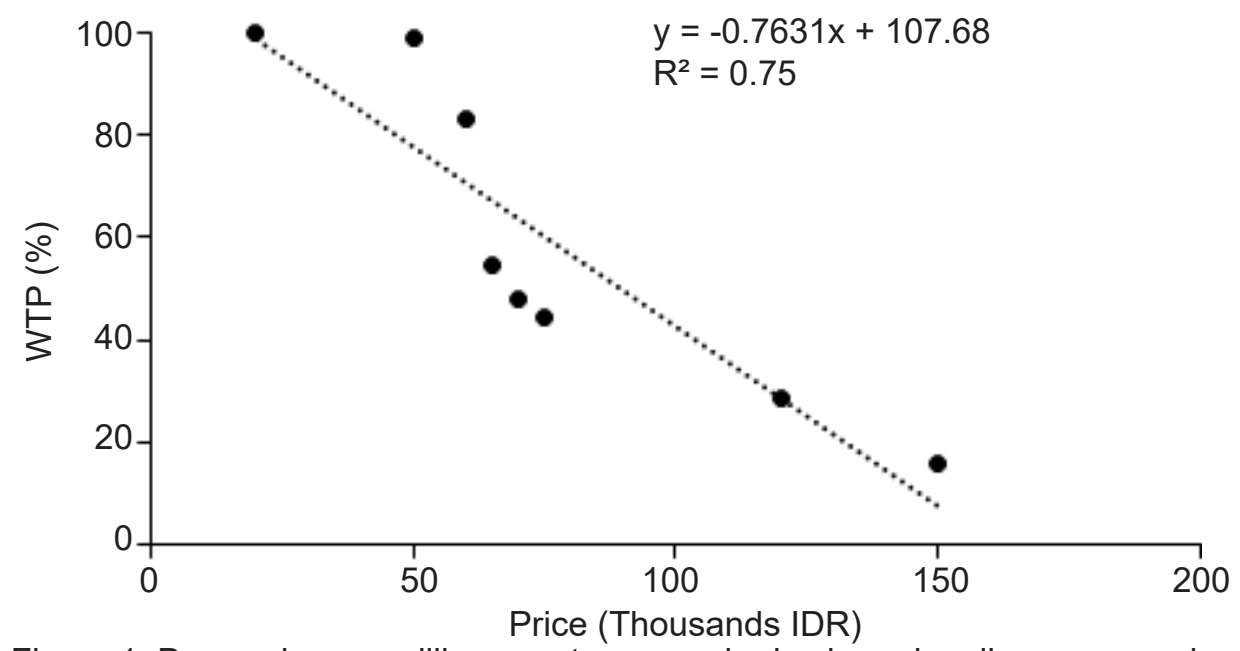

Figure 1 Demand curve willingness to pay and price based on linear regression.

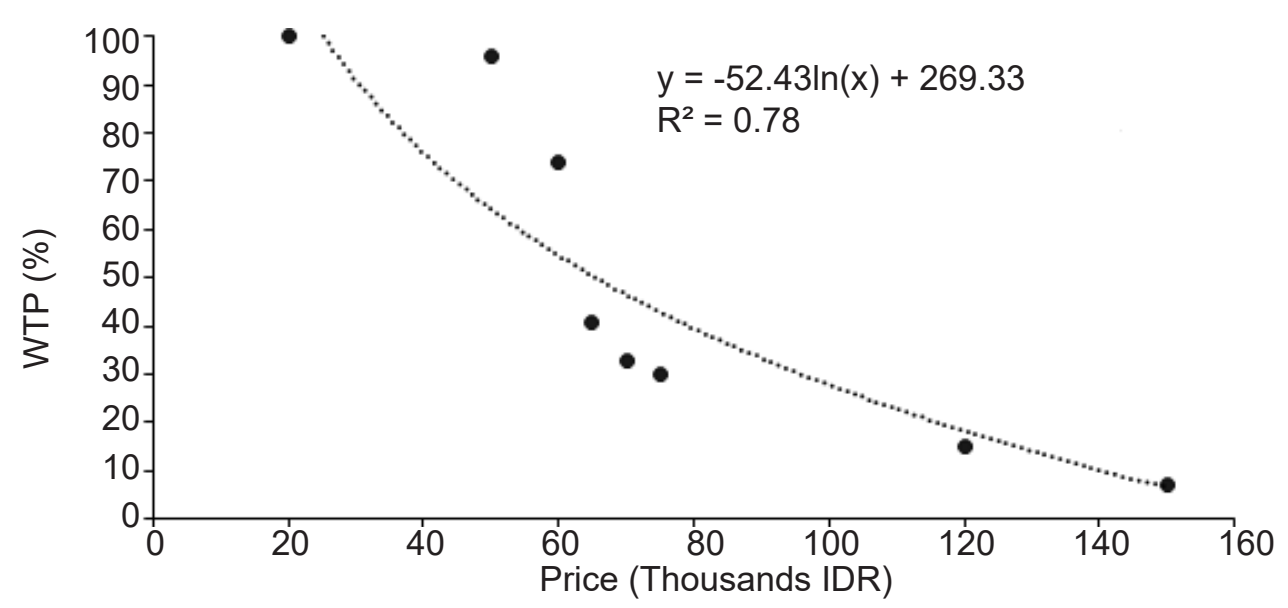

Figure 2 Demand curve willingness to pay and price based on logarithmic regression.

Based on optimal price occurred when derivation of total revenue $(\partial y / \partial x \operatorname{TR})=0$. Optimal price for linear regression model was IDR 70809 and for logarithmic regression model was IDR 62628.

Based on product acceptance, the product can be accepted in African expatriates in Indonesia. Furthermore. this product acceptance confirmed previous research that RPO has been consumed for cullinary purpose for centuries (Cassiday 2017). The product also anticipate environmental issue which has been considered by consumers (Indriantoro et al. 2012; Burhanudin \& Ferguson 2018 ). The raw material of product harvested from Jonggol, Bogor, West Java with no histo- ry of deforestation and processed without refinery so it is environmental friendly.

VRPO as cooking oil has weakness in reddish color fried food. It is still can not be accepted in Indonesian consumers perception. However, VRPO in other purpose and form can be developed because nutrient ingredient for example for new style cullinary and as a supplement food.

There are three alternatives in pricing finding a $1000 \mathrm{~mL}$ VRPO; IDR 70370. IDR 70809 and IDR 62 628. The range initial price suggested from IDR 62628 to IDR 70 809. Drawback open ended question WTP method is respondents tend to give lower price than actual purchasing power. 
There were several limitations in this study, which provide future research opportunities. First, with purposive sampling and limited respondents. the obtained results can be biased for the new product acceptance. Secondly, as preliminary research, this result should be followed by other element marketing mix such as channel distrution (place) and promotion.

\section{CONCLUSION}

The VRPO as a new new product in Indonesia is very potential for African expatriate. The product is similar to the product in their origin countries. Sugested initial pricing range between IDR 62628 to 70809 . The company should develop product with total cost under IDR 62628 including production, packaging, distribution and promotion.

\section{ACKNOWLEDGEMENT}

This preliminary research was supported by Darmono Taniwiryono and Thanks to Allen Onu-Njoku as data enumerator.

\section{REFERENCES}

Andrianto MS, Sukmawati Y, Syamsu K, Budijanto S, Wulandari N. 2012. Market potential of red palm oil (RPO) and derivative product. Proceeding International Conference on Sustainable Business Competitiveness in Indonesian Agribusiness. 25-26 Jun 2012. Bogor (ID): Bogor Agricultural University. pp 82-88. Armstrong G, Kotler P, Opresnik MO. 2017. Marketing An Introduction. $13^{\text {th }}$ Edition. Global Edition. Edinburgh (UK): Pearson Education Limited.

Burhanudin B, Ferguson D. 2018. Environmental issues: managing product switching intentions among Indonesian consumers. J Asia Bus Stud. 12(1):99-
116. DOI: https://doi.org/10.1108/ JABS-06-2015-0066.

Canfield LM, Kaminsky RG, Taren DL. Shaw E, Sander JK. 2001. Red palm oil in the maternal diet increases provitamin A carotenoids in breastmilk and serum of the mother-infant dyad. Eur J Nutr. 40:30-38. DOI: https://doi. org/10.1007/PL00007383.

Cassiday L. 2017. Red palm oil. Inform. 28(2):610. DOI: https://doi.org/10.21748/inform.02.2017.06.

Dwiyanti H, Riyadi H, Rimbawan, Damayanthi E, Sulaeman A. 2014. Penambahan CPO dan RPO sebagai sumber provitamin $A$ terhadap retensi karoten. sifat fisik dan penerimaan gula kelapa. JTIP. 24(1):28-33.

Healy B, Ledwith A, O'Dwyer M. 2014. Perceptions of product advantage. NPD and organisational performance. JSBED. 21(1):49-68. DOI: https://doi. org/10.1108/JSBED-05-2013-0078.

Indriantoro FW, Gumbira Sa'id E, Guritno P. 2012. Rantai nilai produksi minyak sawit berkelanjutan. JMA. 9(2):108116. DOI: https://doi.org/http://dx.doi. org/10.17358/jma.9.2.108-116.

Kritchevsky D. 2000. Impact of red palm oil on human nutrition and health. Food Nutr Bull. 21(2):182-88. DOI: https://doi. org/10.1177/156482650002100212.

Leszczyńska A. 2015. Willingness to pay for green products vs ecological value system. Int J Syn Res. 3:6777. DOI: https://doi.org/10.17951/ ijsr.2014.3.0.67.

Miller KM, Hofstetter $\mathrm{R}$, Krohmer $\mathrm{H}$, Zhang ZJ. 2011. How should consumers' willingness to pay be measured? an empirical comparison of state-ofthe-art approaches. J Mark Res. 43 (February):172-184.

Nagendran B, Unnithan UR, Choo YM, Sundram K. 2000. Characteristics of red palm oil. a carotene- and vitamin E-rich 
refined oil for food uses. Food Nutr Bull. 21(2):189-194. DOI: https://doi. org/10.1177/156482650002100213.

Sugiyono, Wibowo M, Soekopitojo S, Wulandari N. 2012. Pembuatan bahan baku spreads kaya karoten dari minyak sawit merah melalui interesterifikasi enzimatik menggunakan reaktor batch. JTIP. 23(2):117-25. DOI: https://doi. org/10.6066/jtip.2012.23.2.117.

Van Stuijvenberg ME, Faber M, Dhansay MA, Lombard CJ, Vorster N. 2000. Red palm oil as a source of $\beta$-carotene in a school biscuit used to address vitamin
A deficiency in primary school children. Int J Food Scie Nutr. 51:43-50.

Wertenbroch K, Skiera B. 2002. Measuring consumers' willingness to pay at the point of purchase. J Mark Res. 39 (May):228-41.

Widarta IWR, Andarwulan N, Haryati T. 2012. Optimasi proses deasidifikasi dalam pemurnian minyak sawit merah skala pilot plant. JTIP. 23(1):41-46.

Zeba AN, Prével YM, Somé IT, Delisle HF. 2006. The positive impact of red palm oil in school meals on vitamin A status: study in Burkina Faso. J Nutr. 5:1-10. DOI: https://doi.org/10.1186/1475-2891-5-17. 